\title{
ECONOMIC SECURITY OF UKRAINE AND ENTITIES
}

UDC: 351.863:332.055

DOI 10.26906/EiR.2020.4(79).2189

JEL: E60, H56

\section{ANALYSIS OF THREATS SPREAD OF UKRAINE FINANCIAL SECURITY IN A PANDEMIC}

\author{
Svitlana Onyshchenko*, D.Sc. in Economics, Professor \\ Oleksandra Maslii**, PhD (Economics), Associate Professor \\ Yevhenii Kalenichenko***, Student \\ Marina Kotelevets****, Student \\ National University "Yuri Kondratyuk Poltava Polytechnic»
}

*ORCID 0000-0002-6173-4361

**ORCID 0000-0003-2184-968X

\author{
(C) Onyshchenko S., 2020. \\ (C) Maslii O., 2020. \\ (C) Kalenichenko Ye., 2020. \\ (C) Kotelevets M., 2020.
}

Стаття отримана редакиією 21.12.2020p.

The article was received by editorial board on 21.12.2020

Introduction. Ensuring the financial security of Ukraine is relevant, both from a theoretical and practical point of view, especially in modern realities, where there is an unstable development of the world economy due to a number of internal and external factors. This situation weakens the economic potential, hinders the modernization of domestic production and strengthens the competitiveness of the national economy. Along with many threats, large-scale corruption and the shadow economy stand out, which have a significant impact on the financial security of the state. As a result, the inflow of foreign investment remains extremely low, which significantly undermines the development of our country's economy.

In today's conditions, the level of financial security of Ukraine is significantly affected by the COVID19 pandemic, which has become a challenge to financial security and a catalyst for real and potential threats with different levels of impact depending on industry characteristics that prevent profitable activities and functioning of individual businesses.

Many companies are forced to reduce production, supply chains are disrupted due to the inability to sell products or provide services in the usual volumes, which is why the negative effect of the current crisis related to the epidemic danger for the financial security of business is catastrophic. Therefore, the study of financial security of business and the state as a whole is timely and extremely relevant, given the fundamentally new challenges of the pandemic, which have the greatest impact on the functioning of business structures and the financial system of the state.

Review of recent research sources and publications. According to the results of generalization of the results of scientific research of Ukrainian and foreign scientists on the problems of financial security both at the state level and at the level of business entities, such as I. Blank, O. Baranovsky, Z. Varnaliy, V. Martyniuk, T. Vasyltsiv , I. Moiseenko and others, who formed the conceptual foundations of financial security, made a significant contribution to the study of threats to financial security of the state, it should be noted that despite the actualization of this issue, comprehensive study of the emergence, dissemination and search for mechanisms Counteraction to the negative factors influencing the security of the state and 
business structures and ways to minimize threats to Ukraine's financial security in the face of global challenges and fundamentally new threats caused by the COVID-19 pandemic has not yet been carried out.

Problem. From the point of view of ensuring financial security of Ukraine, the purpose of this study is to deepen theoretical provisions, improve methodological and practical recommendations for reducing the impact of corruption, economic shading and threats of the COVID-19 pandemic on the level of financial security of Ukraine and business.

Basic materials and research results. Modern economic realities convincingly show that the prospects, pace and general vector of socio-economic progress of national economies largely depends on the state of economic security of the state, in the system of which an important role is played by the financial component [1].

The latter is the degree of protection of financial interests of the state, the state of the banking, nonbanking financial market, monetary, budgetary, currency, tax and debt systems, characterized by balance and resistance to internal and external threats, the state's ability to effectively generate and use sufficient financial resources. to meet its needs, by fulfilling obligations and ensuring socio-economic development [2].

Financial security can be considered at the micro and macro levels. At the micro level, the abovementioned type of security includes financial security of households and financial security of enterprises. At the macro level, respectively, the financial security of the state is considered, which includes the already mentioned structural components [4].

From the standpoint of the protective approach, the key category of financial security is the threat, the source of which is the uncertainty caused by the properties of social phenomena and processes, in particular, the suddenness of their onset. The problem of defining the economic essence of the basic concepts of financial security, such as "challenge", "risk", "danger" and "threat", which distinguish economic and financial security from traditional economic theory and concepts of economic growth, where the emphasis is not on dangerous economic factors development, and on favorable terms, recognized as the engine of economic development, requires a separate generalization and systematization [9]. Destabilizing factors in the financial sphere are considered to be such phenomena or circumstances that, depending on the strength of the action, may adversely affect the financial condition of the business or the financial stability of the state, which will result in a decrease in financial security.

The threat to financial security is a set of negative security factors that make it impossible and / or hinder the stable functioning of the business entity or the state as a whole and need to be minimized by financial management and other financial security entities implementing preventive measures. As a result of the threat, there is a danger, which is characterized by destructive marginal changes in the financial system, caused by real losses from the threat.

Assessment of financial security at the national level is currently carried out in accordance with the Guidelines for calculating the level of economic security of Ukraine [6]. Based on them, the integrated indicator of financial security is calculated, which is also divided into 6 components. The assessment of financial security is carried out on a system of indicators. In addition, the already mentioned methodology defines not only the names of indicators that can stimulate and have a negative impact on the relevant safety, but also their threshold values (Figure 1).

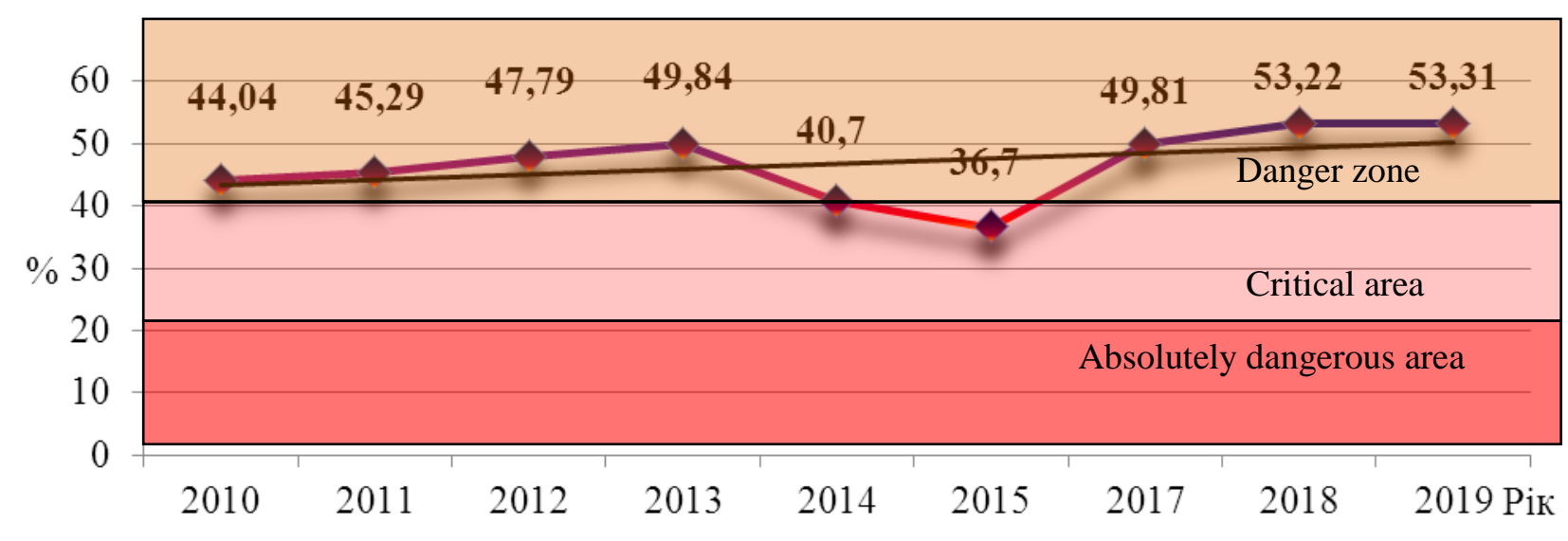

Fig. 1. Dynamics of the level of financial security of Ukraine for 2010 - 2019, \%

Source: authors' calculations 
During the analyzed period there is a low level of financial security of Ukraine, which is a negative trend. As of 2019, the value of 53.31\% is higher than in recent years, but does not indicate an improvement in the financial condition of the state. However, finding the level in the danger zone is negative and needs to be clearly improved.

In modern conditions, the global challenge to financial security of business and the state as a whole is the COVID-19 pandemic, which is a catalyst for real and potential threats with the maximum level of impact on the financial condition and financial results of business entities. factor of formation of financial security of Ukraine and counteraction to real and potential threats should be paid special attention in today's conditions.

Corruption, which is not limited to individual countries and is gaining an international scale, remains no less a problem in Ukraine. And the fight against corruption is one of the most pressing social problems of our time, the solution of which is extremely difficult and important for many countries. For Ukraine, corruption has become a factor that really threatens the constitutional order of the state and its national security.

Corruption is a fairly common problem in every country, and our state is no exception. The imperfection of the legal framework, namely the inconsistency of regulations on the control of economic processes led to serious miscalculations in the initial stages of reforms in the first years of Ukraine's independence, weakening the state system of regulation and control, along with lack of effective public policy. national economy.

The Law of Ukraine "On Prevention of Corruption" defines corruption as the commission by an official who uses the official power granted to him and related opportunities, illegal benefit or promise / offer of such benefit to himself or others [7].

High levels of corruption are a factor influencing the level of financial security, as they have a negative impact on the population and the state as a whole. First of all, it is characterized by a lack of investment attractiveness and the presence of significant economic crime in all economic activities. The dynamics of the rating "Corruption Perceptions Index" shows that our state does not sufficiently develop measures to reduce corruption as a phenomenon that destroys the image of the country and its population in particular (Figure 2).

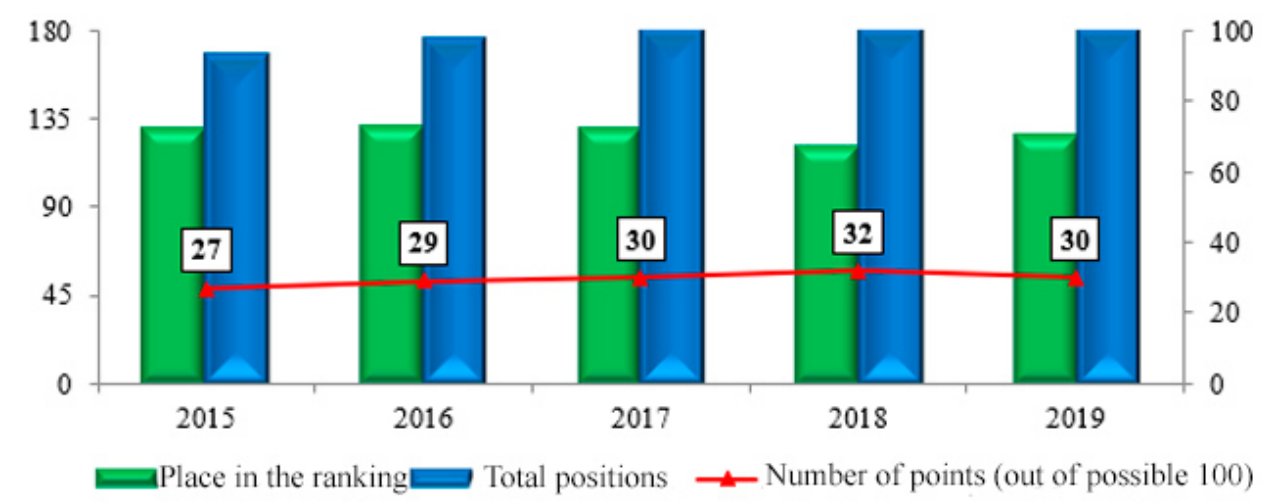

Fig. 2. Ukraine's place in the rating "Corruption Perceptions Index" for 2015-2019 Source: compiled by the authors based on [8]

Since the beginning of 2017, the process of reforms and the fight against corruption has actually been curtailed in Ukraine. The authorities not only reluctantly listened to the advice of civil society and international partners, but also actively opposed it. Over the past couple of years, it has ignored most of the recommendations, and some of them have been critical to the country, leading to a decrease in the country's scores in the rankings and a corresponding increase in its position among other countries.

The constant growth of the shadow sector of the economy poses a significant threat to the security of the national economy. The reasons for the expansion of the shadow sector of the economy are the growth of registered unemployment, which indicates an overflow of labor resources. The consequence of increasing such a threat is a gradual weakening of social protection and reduction of its economic activity together with a decrease in economic growth at the macro level [9].

Ghost economy is formed mainly due to the existence of economic crimes, which are now present in all spheres of Ukraine's economy. The rapid development of crime in the economy has a negative impact on 
society and the state as a whole. The complexity of the fight is that such crimes are constantly changing the ways and forms of illegal activity, which causes difficulties in detection and their latency [10].

According to preliminary calculations of the Ministry of Economic Development, Trade and Agriculture of Ukraine, at the end of 2019 the level of the shadow economy in Ukraine was 29\% of official GDP (Figure $3)$.

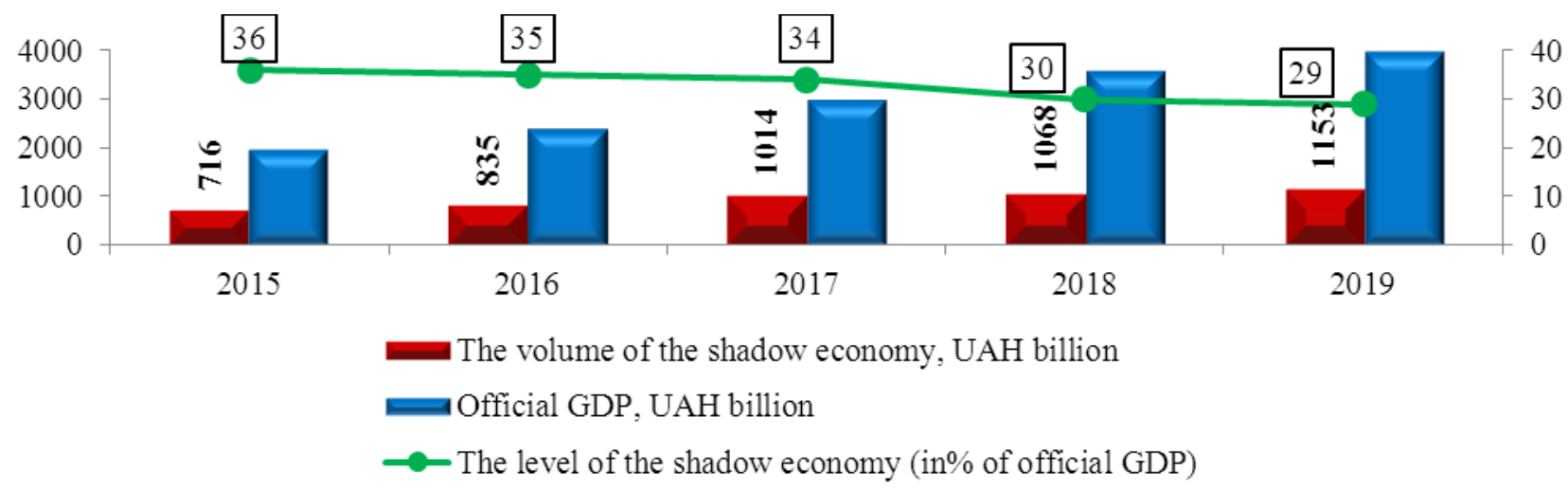

Fig. 3. The level of the shadow economy in Ukraine in terms of official GDP

Source: compiled by the authors based on [12,13]

The data obtained by different methods of calculating the level of the shadow economy, clearly reproduce the behavior of individual market participants in different segments of the national economy (Figure 4).

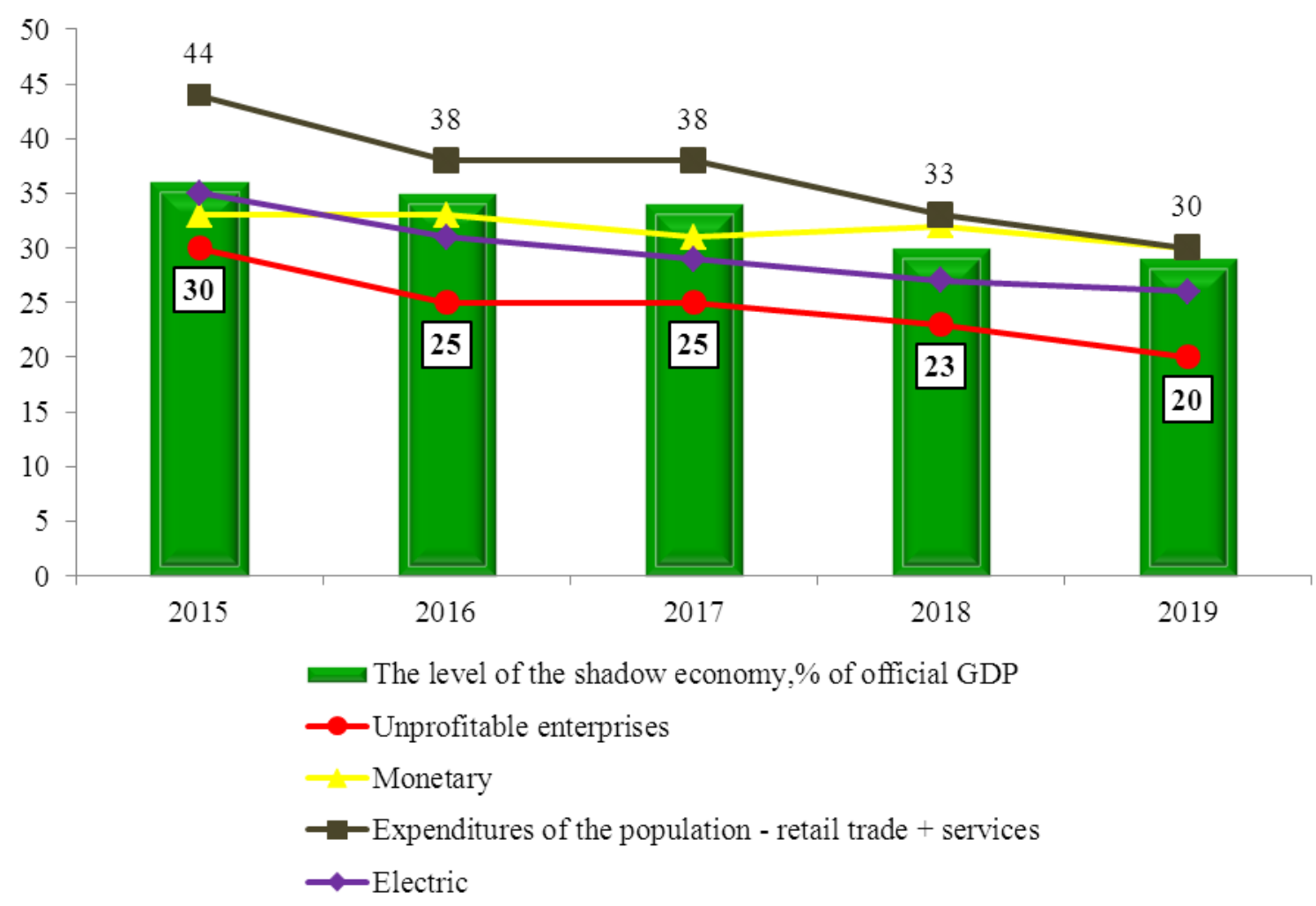

Fig. 4. Dynamics of the level of the shadow economy, calculated by different Source: compiled by the authors based on [13]

As we can see from Figure 4, all the methods used to assess the level of shadowing of the economy, recorded its decline in 2019, compared to the previous period: GDP);

-method "population expenditure - retail trade + services" - for 3 centuries. n. (up to $30 \%$ of official 
-electric method - for $1 \mathrm{n}$. (up to $26 \%$ of official GDP);

- monetary method - for 2 n. (up to $30 \%$ of official GDP);

-the method of unprofitable enterprises - for 3 n. (up to 20\% of official GDP).

To substantiate the impact on the level of financial security of the state of shadow economy and corruption, it is important to investigate the interdependencies between indicators, so we use the tools of correlation and regression analysis.

First, a pairwise linear correlation coefficient is calculated to determine the strength of the relationship. The value of the correlation coefficient -0.68991 . This indicates that during the study period there is a high degree of inverse linear relationship between the levels of financial security of Ukraine and the shadow economy. In this case, the calculated coefficient of elasticity is -0.91 . That is, with the growth of the shadow economy by $1 \%$, the level of financial security of Ukraine decreases by $0.91 \%$.

The next step is to perform regression analysis. The coefficient of determination shows that the variation in the level of financial security is due to the variation in the level of the shadow economy by $47.6 \%$

In general, according to the obtained results, the regression equation and its graphical interpretation has the following form (Figure 5):

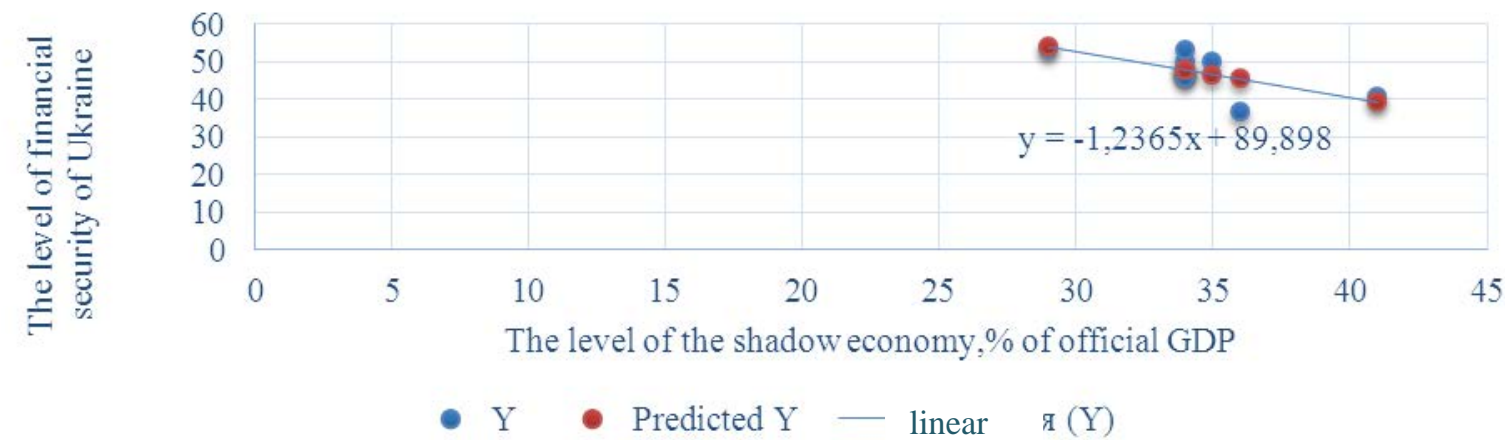

Fig. 5. Dependence of the level of financial security on the level of the shadow economy Source: authors' calculations

The calculated pairwise coefficient of linear correlation, when conducting a study of the relationship between the level of financial security of Ukraine and the index of perception of corruption, showed a direct linear relationship.

The value of the correlation coefficient is 0.51999 . The result of the regression analysis is evidence that the variation in the level of financial security is due to the variation in the level of corruption by $27.0 \%$ In general, according to the obtained results, the regression equation and its graphical interpretation are presented in Figure 6.

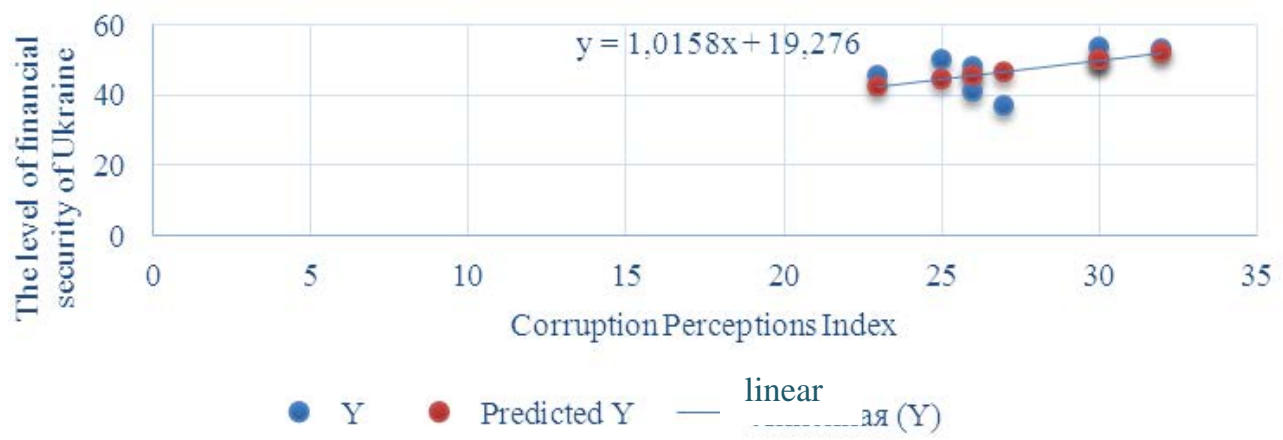

Fig. 6. Dependence of the level of financial security on the corruption perception index Source: authors' calculations

Graphic interpretation of the dependence of the level of financial security of Ukraine on the index of perception of corruption confirms the direct relationship between indicators. The calculated coefficient of 
elasticity is -0.75 . That is, with the growth of the corruption perception index by $1 \%$, the level of financial security of Ukraine increases by $0.75 \%$.

In conditions of instability, business entities face an acute problem of ensuring their financial security, as business activity by its economic nature is risky and associated with a significant number of opportunities on the one hand, and challenges - on the other, which are sources of threats to stable uninterrupted profitable activity of the enterprise and growth of its market value.

In modern conditions, the global challenge to financial security of business is the COVID-19 pandemic, which is a catalyst for real and potential threats with the maximum level of impact on the financial condition and financial performance of businesses, therefore ensuring financial security as a key element and financial security business and countering real and potential threats should be given special attention in today's environment. Assessing the dynamics of key macroeconomic indicators and indicators of economic statistics on business development in Ukraine, it should be noted that almost all sectors of the national economy suffered from the crown crisis due to declining business activity, while the dynamics of the country's overall economic development - real GDP in Ukraine in 2020, as in most countries, is negative compared to the same indicators in 2019, as shown in Figure 7. Thus, the most significant decline in the economy occurred in the second quarter of 2020 - by $11.4 \%$ compared to growth of $4.7 \%$ in in the same period in 2019 and 3.9\% in 2018.

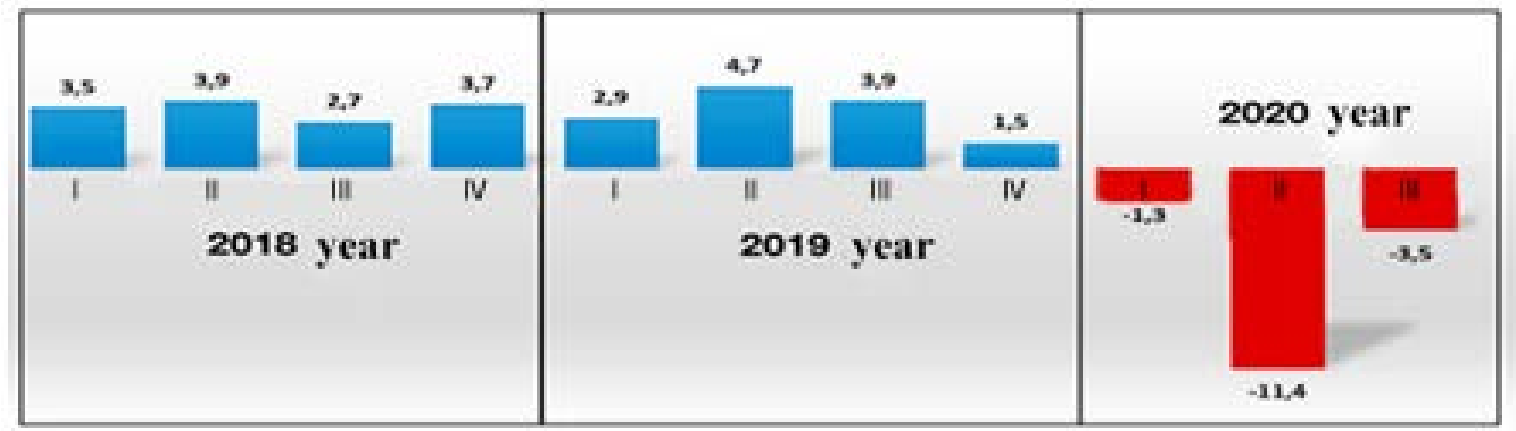

Fig. 7. Dynamics of real GDP of Ukraine in 2018 - 2020, in\% to the corresponding quarter of

Source: complicated by authors based on [12] the previous year

In 2020, one of the main factors influencing economic processes was the spread of the COVID-19 pandemic and the introduction of quarantine restrictions in most countries. The most difficult in the second quarter of 2020 was April - the period of the most severe quarantine measures.

However, the subsequent easing of quarantine restrictions in Ukraine contributed to the gradual resumption of business activity. According to the NBU, the index of business activity expectations in June 2020 was 45.5 points compared to 29.9 points in April 2020 (a record low) and 45.8 points in March 2020. Accordingly, since May we have a decrease in the depth of decline of most economic activities.

Ukraine, like other countries, is experiencing a significant negative impact of the global pandemic, reduced global demand and quarantine measures introduced within the country. In turn, all these factors, despite government support measures, led to a deterioration in the financial security of business, which was reflected in its main indicators, in particular in 2020 there was a sharp reduction in the number of registered businesses - more than a quarter compared to 2019 from 1.942 million to 1.395 million (Figure 8).

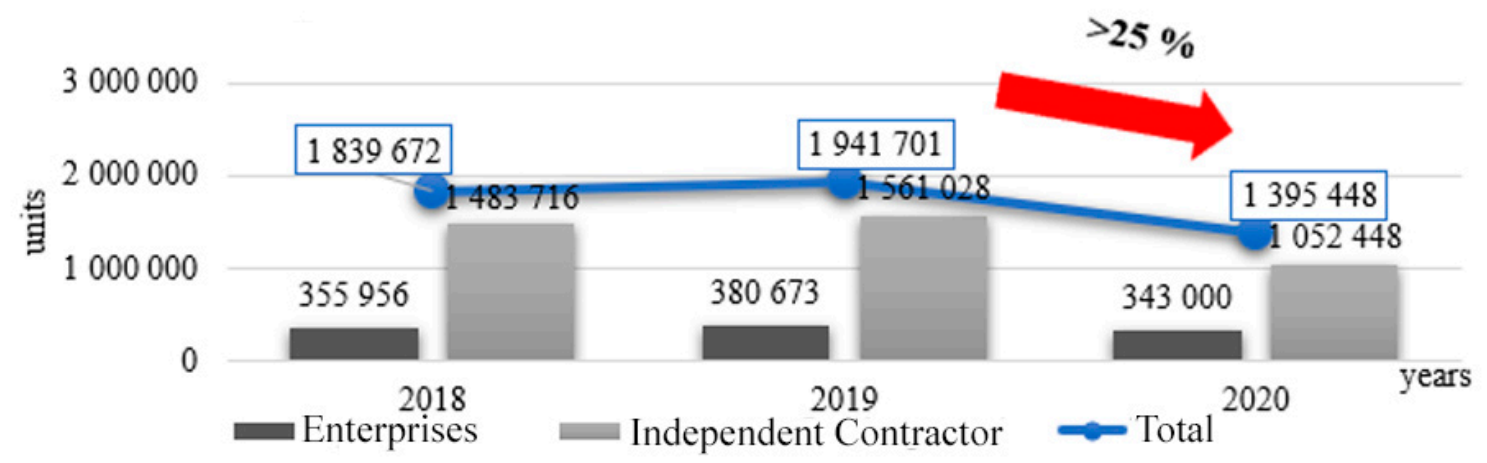

Fig. 8. Quantity of registered business entities in Ukraine in 2018-2020

Source: compiled by the authors based on [14] 
With the beginning of quarantine, small and medium-sized businesses in Ukraine, especially those involved in services, entertainment and food, had to cease their activities. Some businesses have been able to move to other forms of work, but such restructuring has led to significant staff reductions (Figure 9).

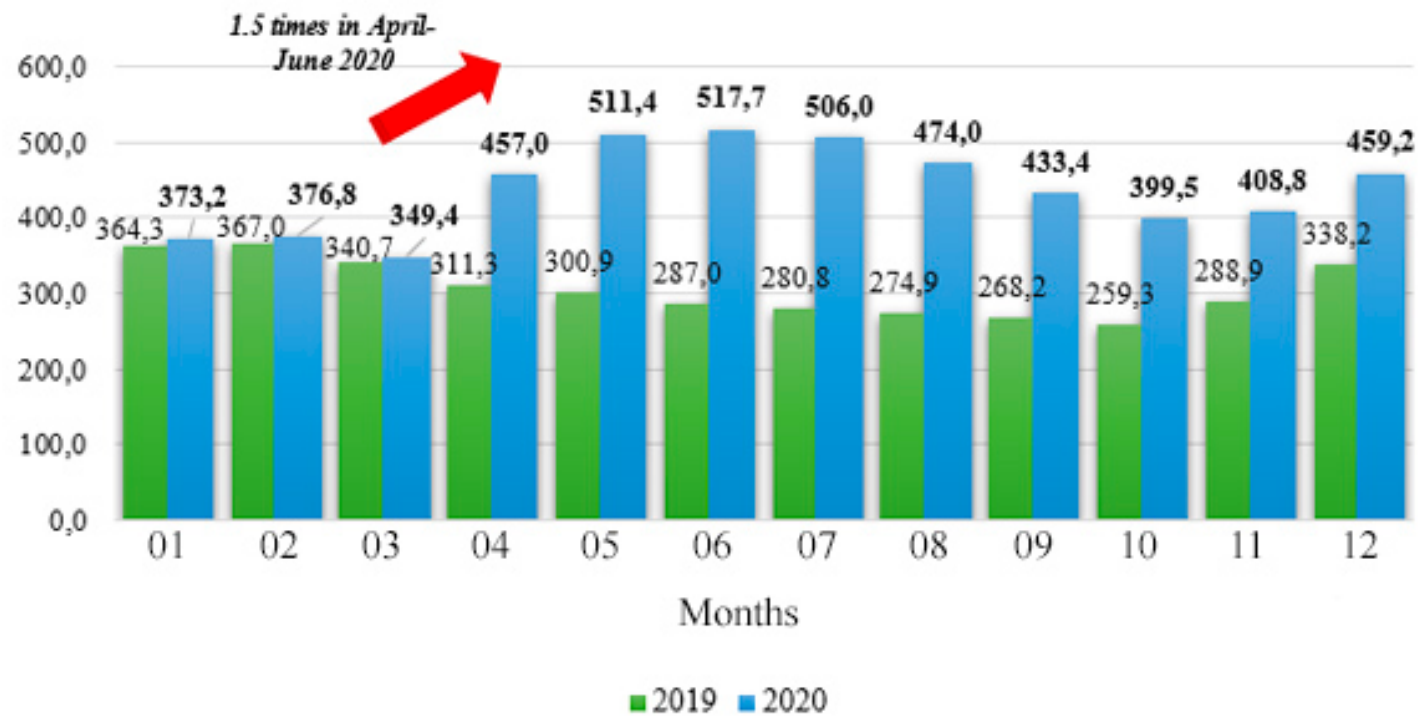

Fig. 9. Number of officially registered unemployed in Ukraine in 2019 and 2020, thousand people

Source: compiled by the authors based on [15]

Some businesses, due to quarantine restrictions, made redundancies or went on vacation at their own expense. At the same time, in June the number of unemployed began to decline compared to May and April. In general, this is a seasonal phenomenon, and the fact that this year the trend has not been broken, indicates a gradual return of the economy to the "usual" order of affairs.

Profitability of operating activities is one of the main indicators of financial security of business, which shows the efficiency of production and sales and can be positive even in the presence of net loss.

Most enterprises have positive values of this indicator for the studied 2019. However, in 2020 the figure drops to $50.0 \%$. That is, the production of half of the surveyed entities is unprofitable (Figure 10).

Unprofitable enterprises, the presence of uncovered losses of previous years, low profitability hinders the preservation of financial stability and a sufficient level of financial security of business, increases business risk, reduces investment attractiveness, harms the corporate image. Lack of profits and high costs, which leads to low profitability, does not allow the company to meet the needs of employees in the appropriate level of wages and social security.

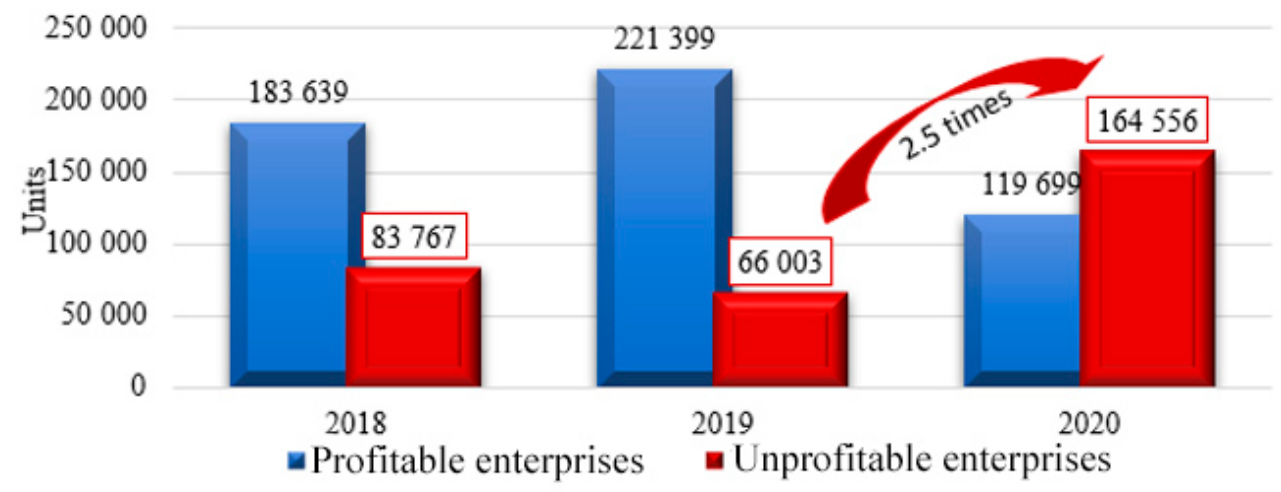

Fig. 10. The ratio of profitable and unprofitable enterprises of Ukraine in 2018-2020

Source: compiled by the authors based on [12] 
Having analyzed in detail the actions of governments, it can be noted that the Ukrainian government has eased external pressure on business by providing some benefits and discounts, as well as minimum wage compensation for employers, however, this will usually not be enough to support small and medium business in Ukraine in the conditions of the maximum influence of global challenges and threats. All these measures should somewhat reduce the burden on Ukrainian business, but, in our opinion, this will not significantly affect the overall decline in business activity and will not compensate for the significant loss of profits.

Adaptive management in the face of real threats will not only minimize financial risks for business, but also create a foundation for further business development in the post-crisis period, when the impact of the threat will be reduced. The modern realities of business should be based on a new communication strategy, based on constant communication between the company's employees, and all decisions should be agreed and promptly communicated to colleagues, which is extremely important for the effective evolution of business in the face of existing challenges.

Conclusions. The modern paradigm of security shows that financial security is a component of economic security of the state and occupies an important place in its structure. Given a sufficient level of financial security at the macro level, stable development of the financial potential of the state is ensured.

It is established that the shadow economy of Ukraine is due to the instability of the economic environment, the lack of appropriate favorable conditions for business entities for further successful business development within the legal economy, the creation of which is an urgent task of the state. As for corruption, this phenomenon is observed in all spheres of employment of the national economy, thus generating constant economic crime.

It was found that the main reason for the growth of corruption is that officials consider their positions as a tool for personal gain, and control over the actions of such persons by law enforcement agencies is insufficient. The main preconditions for a high level of shadowing of the economy are inefficient institutional basis for business regulation, bureaucratization of the state apparatus, instability of tax legislation, inefficiency of the judiciary and law enforcement agencies and unsatisfactory conditions for doing business.

The integrated level of financial security of Ukraine is analyzed according to 32 indicators for determining the level of financial security of the state. The level of financial security of Ukraine is in a dangerous zone and needs to be clearly improved. The relationship between the level of financial security of the state and the levels of the shadow economy and corruption has been studied using correlation-regression analysis. The value of the correlation coefficient indicates a high degree of direct linear relationship between the level of financial security of Ukraine and the level of the shadow economy, whereas the shadow economy increases, the level of financial security decreases significantly. In the process of assessing the impact of corruption on the financial security of the state, an inverse relationship has been established, which is characterized by the fact that when corruption decreases or the index of its perception increases, the level of financial security increases accordingly.

The development of business and ensuring its target parameters of financial security in a crisis will minimize the negative impact of modern threats associated with quarantine restrictions, both at the level of individual regions and the country as a whole; ensure the rational use of all types of resources, including financial; will form a competitive environment in business in the post-crisis period; provide incentives for the introduction of information and communication technologies and innovation processes in the framework of the fourth industrial revolution and the digitalization of the economy and highly efficient activities of the country as a whole.

\section{REFERENCES:}

1. Varnaliy, Z. (2009). Economic security. Kyiv: Knowledge (in Ukr.).

2. Baranovskyi, O. (2000). Financial Security in Ukraine (assessment, methodology and mechanism for maintenance). Kyiv: Institute for Economic Forecasting of Ukrainian National Academy of Sciences (in Ukr.).

3. Martyniuk, V., Zvoliak, Y. \& Baranetska, O. (2016). Finansova bezpeka [Financial security]. Ternopil: Vector (in Ukr.).

4. Ladyuk, O. (2016). Financial security: characteristics of components. Effective economy, 11 Retrieved from http://www.economy.nayka.com.ua/ ?op=1\&z=5280

5. Varnaliy, Z., Onishchenko, S. \& Masliy, A. (2016). Threat prevention mechanisms of Ukraine's economic security. Economic Annals-XXI, 159 (5-6), 20-24. DOI: http://dx.doi.org/10.21003/ea.V159-04. 
6. The Ministry of Economic Development and Trade of Ukraine (2013, 29 October). On approval of methodological recommendations for calculating the level of economic security of Ukraine (Working Paper No 1277). Retrieved from: http://me.kmu.gov.ua/

7. The Law of Ukraine $(2014,14$ October). On Prevention of Corruption (Working Paper No. 001700-VII). Retrieved from: https://zakon.rada.gov.ua/laws/show/ 1700-18\#Text.

8. Transparency International (2020). Retrieved from https://ti-ukraine.org

9. Onishchenko, S. \& Pugach, A. (2015). Threats to economic security of Ukraine: essence, evaluation and prevention mechanism. Poltava: PoltNTU (in Ukr.).

10. Kharazishvili, Yu. (2014). Methodological approaches to assessing the level of economic security of the country. Science and Science of Science, 4, 44-58 (in Ukr.). Ukr.).

11. Varnaliy, Z. (2006). Shadow economy: essence, features and ways of legalization. Kyiv: NISS (in

12. State Statistics Service of Ukraine (2020). Statistical information. Retrieved from http://www.ukrstat.gov.ua (in Ukr.)

13. The Ministry for Development of Economy, Trade and Agriculture of Ukraine (2020). Retrieved from https://www.me.gov.ua/?lang=uk-UA

14. The State Tax Service of Ukraine (2020). Retrieved from https://tax.gov.ua/

15. The State Employment Service of Ukraine (2020). Data on the number of registered unemployed and the provision of services, as well as the number of registered vacancies Retrieved from https://www.dcz.gov.ua/publikaciya/1-dani-shchodo-kilkosti-zareyestro vanyh-bezrobitnyh-ta-nadannyayim-poslug-takozh

16. Onyshchenko, S., Maslii, O. \& Ivaniuk, B. (2020). The Impact of the External Environment on the Economic Security of Ukrainian Business. Economics and Region, 1(76), 22-29. doi:https://doi.org/10.26906/EiR.2020.1(76).1914.

UDC: 351.863:332.055

JEL: E60, H56

Онищенко Світлана Володимирівна, доктор економічних наук, професор. Маслій Олександра Анатоліївна, кандидат економічних наук, доцент. Каленіченко Євгеній Сергійович, студент. Котелевець Марина Миколаївна, студентка. Національний університет «Полтавська політехніка імені Юрія Кондратюка». Аналіз поширення загроз фінансовій безпеці України в умовах пандемії. Висвітлено теоретичні засади фінансової безпеки та ії місце в загальній системі національної економіки. Обгрунтовано, що 3 позицій захисного підходу ключовою категорією фінансової безпеки $є$ загроза, джерелом якої $є$ невизначеність, що обумовлена властивостями суспільних явищ і процесів, зокрема, раптовістю їх настання. Розкрито економічну сутність загроз і схарактеризовано їх вплив на фінансову безпеку бізнесу. Досліджено основні деструктивні чинники впливу тінізації економіки та корупції на фінансову безпеку й виокремлено причини їх поширення в Україні. Проаналізовано тенденції рівня фінансової безпеки в контексті порівняння його 3 нормативними значеннями. Доведено, що в сучасних умовах глобальним викликом фінансовій безпеці бізнесу та держави в цілому є пандемія COVID-19, яка є каталізатором реальних та потенційних загроз з максимальним рівнем впливу на фінансовий стан та фінансові результати діяльності суб'єктів бізнесу. Розглянуто корупцію та тіньову економіку за різними методичними підходами, а також на основі кореляційно-регресійного аналізу. Визначено взаємозв'язок впливу корупції й тіньової економіки на рівень фінансової безпеки України. Виявлено високу ступінь оберненого лінійного взаємозв'язку між рівнями фінансової безпеки України та тіньової економіки й корупції. Проаналізовано та надано оцінку впливу загроз на фінансову безпеку бізнесу в Україні в умовах пандемії. Доведено, що розвиток бізнесу та забезпечення його цільових параметрів фінансової безпеки в умовах кризи дозволить мінімізувати негативний вплив сучасних загроз, пов'язаних із карантинними обмеженнями. Визначено пріоритетні напрями мінімізації загроз фінансовій безпеці бізнесу в умовах епідемічної небезпеки. Доведено, що адаптивне управління в умовах реальних загроз не тільки забезпечить мінімізацію фінансових ризиків для бізнесу, але і створить фундамент для подальшого розвитку бізнесу в посткризовий період, коли вплив загрози буде зменшений.

Ключові слова: фінансова безпека, корупція, тіньова економіка, безпека бізнесу, виклик, загроза, пандемія. 
UDC: 351.863:332.055

JEL: E60, H56

Onyshchenko Svitlana, Doctor of Economics, Professor. Maslii Oleksandra, PhD in Economics, Associate Professor. Kalenichenko Yevhenii, student. Kotelevets Marina, student. National University «Yuri Kondratyuk Poltava Polytechnic». Analysis of Threats Spread of Ukraine Financial Security in a Pandemic. Theoretical principles of financial security and its place in the general system of the national economy were covered. It is noted that from the standpoint of the protective approach the key category of financial security is the threat, the source of which is the uncertainty caused by the properties of social phenomena and processes. The economic essence of threats was revealed and their impact on the financial security of business was characterized. The main destructive factors of the shadow economy and corruption on financial security were studied and the reasons for their spread in Ukraine were highlighted. Trends in the level of financial security in the context of comparing it with regulatory values were analyzed. It is proved that the global challenge to financial security of business and the state as a whole is the COVID-19 pandemic, which is a catalyst for real and potential threats with the maximum level of impact on the financial condition and financial results of business entities in modern conditions. Corruption and the shadow economy were considered according to different methodological approaches, as well as on the basis of correlation-regression analysis. The relationship between the impact of corruption and the shadow economy on the level of financial security of Ukraine has been determined. A high direct linear relationship between the levels of financial security of Ukraine and the shadow economy and corruption was detected. The impact of threats on the financial security of business in Ukraine in a pandemic was analyzed and assessed. It is proved that development of business and ensuring its target parameters of financial security in a crisis would minimize the negative impact of modern threats associated with quarantine restrictions. The priority directions of minimization of threats to financial security of business in the conditions of epidemic danger were defined. It is proved that adaptive management in the face of real threats can minimize financial risks for business and create a foundation for further business development in the post-crisis period, when the impact of the threat would be reduced. pandemic.

Key words: financial security, corruption, shadow economy, business security, challenge, threat, 